\title{
Krigens fjendebilleder: Kosovokrisen 1998-99 som informationskrig
}

\author{
Af Karsten Fledelius
}

Artiklen er en kritisk historisk analyse af, hoordan NATOs krigsmessige indsats mod Serbien-Montenegro if foråret 1999 blev ledsaget af en mediemassig offensiv, der satte vestlige nyhedsmedier under pres for at bakke op om krigen. Medierne viste sig at have begrenset modstandskraft, og en klodset serbisk mediestrategi gjorde sit til, at det lykkedes at fä hovedparten af presse, to og radio $i$ de vestlige lande til at acceptere den uerklarede krig som legitim, ja, endda legal - selvom tilgangelige oplysninger burde have skabt en mere analytisk og kritisk holdning til NATOs informationsstrategi.

Krigene i det tidligere Jugoslavien var i høj grad informationskrige. I verden omkring Balkan var der generelt lille viden om forholdene, og endnu mindre lyst til at blande sig i dem. Dén, der fik held til at etablere sin diskurs som den almindeligt udbredte, havde et forspring for andre parter. Diskurserne trak normalt meget på fortiden og de forventninger, man måtte have til fremtiden på baggrund af den. Derfor kom gamle fjendebilleder fra Anden Verdenskrig og helt tilbage til middelalderen til at spille en stor rolle.

De første informationskrige foregik inden for rammerne af det tidligere Jugoslavien, efter at det kommunistiske Jugoslaviens skaber og hersker, præsident Josip Broz Tito, var død i 1980. Etniske albaneres krav om ikke blot albansk flertalsstyre for Kosovoprovinsen, men løsrivelse fra Serbien, udløste i april 1981 de første uroligheder, som blev hårdhændet nedkæmpet af provinsens politistyrke, der var under kontrol af provinsens albanskdominerede kommunistparti. I 90'erne blev også udlandet inddraget i informationskrigene, i stigende grad efter udbruddet af åben krig i juni 1991 og især efter sammenbruddet $\mathrm{i}$ fredsforhandlingerne i juni 1993. Denne 'globalisering' af krigen på mediefronten er særlig udtalt under Kosovo-konflikten i 1998-99.

\section{Kosovo i 80'erne}

Kosovo var 1974-89 en provins med forfatningsmæssig særstilling og vidtgående selvstyre inden for den serbiske republik i Jugoslavien. Provinsen havde allerede ved afslutningen af Anden Verdenskrig albansk flertal, og dette øgedes gennem årene, så mere end 77 procent af befolkningen var etniske albanere i 1981, det år de første uroligheder fandt sted (Mønnesland, 1992, s. 328). I de følgende år var det især fra den serbisk-ortodokse kirke, at der blev klaget over albanske overgreb mod kirker og klostre i provinsen og angivelige forsøg på at styrke det albanske befolkningsoverskud med flere barnefødsler (Fledelius, 2003, s. 199-205). Der skabtes derudover en bevægelse af nationalistiske serbere, som informerede - og fejlinformerede - om antallet af voldshandlinger begået af albanere mod serbere, især voldtægter (Ackerman \& Naurecklas, 2000, s. 98f; Thompson, 1999, s. 53-5). En uafhængig undersøgelse gennemført af antinationalistiske serbere i Beograd viste dog, at antallet af sådanne voldshandlinger $\mathrm{i}$ provinsen var under gennemsnittet, og at man ikke kunne tale om en bølge af vold rettet mod det serbiske mindretal, hvis formål skulle være at få serberne til at flytte ud af provinsen. 
Der var en serbisk afvandring fra Kosovo, men den skyldtes især provinsens fattigdom i forhold til andre dele af Jugoslavien - også mange albanske kosovoboere udvandrede. Men i en anset hovedstadsavis som dagbladet Politika vandt antialbanske nyheder adgang og satte ledelsen af det serbiske kommunistparti i Beograd under pres, suppleret af rædselsberetninger i andre serbiske medier og massemøder af Kosovoserbere, der krævede indgreb mod provinsregeringen i Prishtina. Det samme gjorde et memorandum fra det Serbiske Akademi for Videnskab og Kunst fra 1986, som betegnede forholdene i Kosovo som præget af storalbanske racisters genocide bestræbelser for at skabe et rent albansk Kosovo (Fledelius, 1999, s. 105f).

Det serbiske kommunistparti havde i maj 1986 enstemmigt fået en ny leder, Slobodan Milosevic. Hans gode ven og mentor, Serbiens præsident Ivan Stambolic, sendte ham til Kosovo for at dæmpe de serbiske gemytter. Men Milosevic vendte dernede på en tallerken ved et massemøde d. 24. april 1987, og i de følgende måneder blev antallet af rædselshistorier i medierne øget. Således blev en massakre foretaget af en kosovoalbansk soldat på kasernen i byen Paracin d. 3. september, hvor fire omkom, fem blev såret og gerningsmanden skød sig selv, blæst op i medierne og gjort til en del af en antiserbisk konspiration mod hele Jugoslavien (Mertus, 1999, s. 145-54). På denne baggrund fik Milosevic d. 23. september 1987 endelig udmanøvreret Stambolic og selv placeret sig som Serbiens øverste politiske leder (Silber \& Little, 1995, s. 36-48; Fledelius, 1999, s. 49). Den følgende tid styrkede han sit herredømme over de serbiske medier, herunder tv, og skabte derved forudsætningerne for sine kup først mod lokalregeringerne i den nordserbiske autonome provins Vojvodina og den lille naborepublik Montenegro, derefter mod det albanske flertalsstyre i Kosovo i marts 1989, der understøttedes af militær magtanvendelse (Silber \& Little, 1995, s. 60-73).

Det var en populær aktion hos de nationalistisk vakte serbere, for hvem Kosovo var erklæret hellig serbisk jord, dels pga. et legendeombølget nederlag til tyrkerne i 1389, dels i kraft af de mange middelalderlige serbiskortodokse kirker og klostre i provinsen. For albanerne var Kosovo det sted, den moderne albanske nationalbevægelse udsprang. Desuden hævdede de, at der kun havde levet serbere i Kosovo i lidt over 1000 år, mens albanernes forfædre havde boet der i over 3000. Derfor gør begge folkeslag krav på den fattige provins.

\section{Jugoslaviens opløsning og dens forberedelse i medierne}

Kuppet i 1989 blev igangsættende for den disintegrationsproces, der førte til krig og opløsning i Jugoslavien i 1991-92. Og den accelererede kampene i de jugoslaviske medier. Større reel ytringsfrihed i anden halvdel af 80'erne gav forskellige resultater i de forskellige jugoslaviske republikker. I Slovenien og Kroatien udløste udviklingen i Serbien stærke reaktioner, og ved de første valg med flere partier i 1990 vandt nye nationalistiske partier over kommunisterne både i Kroatien og Bosnien-Hercegovina. I Slovenien, Serbien, Montenegro og Makedonien var det godt nok kommunisterne, der sejrede, men som reformerede, nationalistiske socialistpartier.

Overalt i landet steg nu temperaturen i retorikken, og de første større udrensninger af journalister, som forsøgte at holde en moderat og afbalanceret linie, fandt sted, ikke mindst på tv. Her havde der hidtil været et godt samarbejde med udveksling af reportager mellem de forskellige republikkers tv-stationer (Thompson, 1999, s. 16-8). Men nu blev også dette vigtigste af alle massemedier for alvor inddraget $\mathrm{i}$ den indre mediekrig, som var $\mathrm{i}$ fuld gang forud for starten på de fysiske krigshandlinger i 1991 og blev yderligere intensiveret i det første krigsår ved en radio- og tv-lov, som placerede RTS, det offentlige Radio-Televizija Srbija, direkte under den serbiske regering (Milinkovic, 1993, s. 111). En heksejagt på kritiske journalister satte ind, anført af lederen for det Serbiske Radikale Parti, professor Vojislav Seselj, og et forsøg på en tv- og radiostrejke løb ud i sandet. For tv's vedkommende betød de udenlandske sanktioner fra 1992 en øget vægt på tv som det centrale nyhedsmedie (Sommelius, 1993, s. 58-61).

Hos Kosovo-albanerne var reaktionen at vende den afsatte kommunistiske provinsledelse ryggen, i 1990 vælge et illegalt parlament og en illegal præsident, dr. Ibrahim Rugova, og opbygge et parallelsamfund til det serbiskdominerede. Rugovas forbillede var Mahatma Gandhi, han håbede at kunne slide serbernes modstand op med fredelige midler som civil ulydighed.

\section{Mediekrigens ydre fronter}

Fra udlandet sendte store kosovoalbanske udvandrergrupper på begge sider af Atlanten penge til opbygningen af det alternative kosovoalbanske 
samfund. De var særlig aktive i Tyskland og USA. Det samme gjaldt i øvrigt den kroatiske løsrivelsesbevægelse, hvis leder, dr. Franjo Tudjman, der blev Kroatiens præsident i 1990, i høj grad fik støtte fra emigranter i Vesteuropa og Nord- og Sydamerika. Dette viste sig også på mediefronten, hvor der bl.a. foregik en produktion af propagandistiske videoer distribueret på VHS. Dette fænomen, som blev særlig udbredt efter krigsudbruddet i 1991, blev også anvendt af serbiske og makedoniske nationalister, og senere af de bosniske, først og fremmest med emigrantmiljøerne som målgrupper (KolarPanov, 1997, s. 44-75). Senere blev internettet en vigtig arena for denne form for mediekrig, hvilket blandt andet viste sig i de radikale makedonske udlandsnationalisters hadske udfald mod Makedoniens moderate præsident Gligorov forud for attentatforsøget på ham i 1995.

Kosovoalbanerne forsøgte at gøre opmærksom på deres sag ude omkring i verden, bl.a. ved brug af telefax og internet, men uden det store held; den druknede i de voldsomme begivenheder i Bosnien. Endvidere blev Kosovo, også provinsens albanere, ramt af den internationale blokade mod Serbien og Montenegro. Deres ufravigelige mål var fuld selvstændighed. Det var det klare mål for både mere moderate kosovoalbanske ledere som dr. Ibrahim Rugova og mere radikale personligheder som Adem Demaçi, leder af et menneskerettighedscenter i Prishtina. Begge stod kompromisløst for fuld selvstændighed, altså løsrivelse ikke blot fra Serbien, men fra Jugoslavien som helhed. Adem Demaçi betegnede det i en samtale med en dansk nødhjælpsdelegation i december 1993, jeg selv deltog i, som en håndsrækning fra kosovoalbanerne, at man ikke ville kræve en forening af albanerne i Eksjugoslavien med republikken Albanien, men ville stille sig tilfreds med en uafhængig Kosovorepublik.

Ved fredsforhandlingerne i november 1995 i Dayton, Ohio, hvor der blev sat en stopper for krigen i Kroatien og Bosnien, blev Kosovo ikke inddraget. Milosevic havde formået at holde Kosovo ude af Dayton-forhandlingerne som et indre serbisk anliggende, og den amerikanske chefforhandler Richard Holbrooke havde ladet problemet ligge for at redde den komplicerede fredsslutning $\mathrm{i}$ land. Men det var klart, at en normalisering af Serbiens forhold til udlandet også indebar en mere demokratisk ordning for Kosovo, selv om der ikke var opbakning hverken fra amerikansk eller europæisk side til fuld selvstændighed for Kosovo. Og slet ikke fra russisk side, hvor man naturligvis måtte se en parallel mellem Kosovo og Tjetjenien. Så Kosovo blev liggende som en tikkende bombe.

\section{Nye forbundsfaller}

November 1996 skulle præsidentvalget i USA afgøres. Det var den republikanske senator Dole mod den siddende præsident Clinton. Dole var væsentlig ældre end Clinton og langt fra så karismatisk. De albanske emigrantkredse i USA stod først bag Dole, men besluttede sig så til at gå over til Clinton for at være på den sandsynlige vinders side. Det betød ikke, at Clinton dermed blev stærkt afhængig af den kosovo-albanske lobby. Men det var klart for albanerne, at der var bedre muligheder for at bringe Kosovo på det internationale samfunds agenda gennem det amerikanske politiske system end gennem EU eller FN, hvor der var en traditionel afstandtagen fra provinser, der forsøger at rive sig løs fra deres 'moderstater'.

En af de mere vidtrækkende beslutninger, præsident Clinton traf i forbindelse med sit genvalg i slutningen af 1996, var at gøre sin hidtidige ambassadør i FN, den tjekkiskfødte professor Madeleine Albright, til amerikansk udenrigsminister. Hermed var der lagt op til en mere aktivistisk udenrigspolitisk linie end med den forsigtige og meget diplomatiske Warren Christopher. Albright havde allerede demonstreret sine holdninger i forbindelsen med en militær afsættelse af den folkevalgte præsident på Haiti, Aristide, hvor det var lykkedes hende at fjerne kupregimet med en trussel om militær intervention. Hun havde her vist den holdning, at det var fint, hvis man kunne handle med opbakning fra $\mathrm{FN}$, men at manglende opbakning herfra ikke skulle forhindre USA $i$ at gribe ind mod vold og undertrykkelse. Faktisk lykkedes det hende at sikre stort flertal og ingen veto i FN's sikkerhedsråd for en amerikanskledet militær intervention på Haiti, som altså viste sig at blive fredelig, fordi kupgeneralen gav op (Albright, 2003, s. 156-60). Albright var hverken mod væbnede konfrontationer eller støtte til indre kræfter, som modarbejdede udemokratisk regimer, og hun så USA i en lederrolle i kampen for en mere demokratisk verden. Hendes indstilling til personer som Saddam Hussein og Slobodan Milosevic var den samme: De burde fjernes, og hun skulle nok gøre sit. Allerede i 1993 var hun som FN-ambassadør eksploderet over for generalstabschef Colin Powell med ordene: "Hvad 
er meningen med at have dette fantastiske militær, du altid taler om, hvis vi ikke må anvende det?" (Powell, 1995, s. 576; cf. Owen, 1995, s. 138).

Albrights aktivistiske linie blev bakket op af Storbritanniens nye premierminister fra 1997, Tony Blair. Han anlagde en stærkt moralsk linie i sin udenrigspolitik og nærmede sig USA, hvis præsident han fik et nært og hjerteligt forhold til. Der tegnede sig konturerne til et intensiveret angelsaksisk samarbejde over Atlanten, med en styrkelse af fælles samarbejdsorganisationer, i første række NATO. Både Blair og Albright havde et glimrende forhold til medierne og udnyttede dem gerne i deres politik. For en præsident som Bill Clinton, der var presset af Lewinsky-affæren, var Albrights udadvendte stil og evne til at formulere andre dagsordener en gevinst.

\section{Kosovokrisen 1998}

D. 15. januar 1998 opfyldte Milosevic det sidste territoriale krav fra Dayton-aftalen, idet Østslavonien, hidtil serbiskdomineret under FN-kontrol, blev overdraget til Kroatien. En amerikansk diplomat lykønskede Serbien, og der syntes endelig at være basis for ophævelse af de sidste sanktioner mod Jugoslavien, et centralt mål for Milosevics politik. Men i samme måned begyndte en organisation, der kaldte sig Kosovas Befrielseshær, UÇK, at udføre koordinerede natlige angreb på serbiske politifolk i provinsen. Allerede i marts var der tale om sammenstød i større målestok mellem serbiske enheder og albanske oprørere. Og krisen eskalerede i de følgende måneder.

Den blev hurtigt internationaliseret på medieområdet. Både fra eksilalbansk side, hvor Rugovas parti havde informationskontorer i udlandet, og fra serbisk. Som i de forrige år spillede telefax til presse, elektroniske medier, meningsdannere og politikere en betydelig rolle. Men også internettet blev af stigende betydning, hvor e-mail overtog faxens rolle.

Den nye konflikt betød et ryk til højre i serbisk politik, og den ultranationalistiske politiker Seselj, der havde været den største politiske trussel mod Milosevic i 1997, blev optaget i regeringen. Han havde i 97 lovet, at hvis han blev præsident i Serbien, ville han løse Kosovoproblemet på fem dage. Trods amerikanske advarsler så styret i Beograd ingen anden udvej end at besvare den opståede og eskalerende militære trussel med militære midler.
Madeleine Albrights holdning var klar: Serberne havde lovet USA at reagere med moderation mod UÇK. De havde løjet. Deres optrapning af konflikten ville radikalisere albanerne, styrke UÇK og svække de moderate albanske politikere. Hun fandt en meningsfælle i den engelske udenrigsminister Robin Cook, og på et møde i London i den internationale kontaktgruppe, der 1997 var blevet udvidet med Italien, forsøgte hun at skabe fælles fodslag om at anvende det eneste sprog, Milosevic angiveligt forstod: Magt - og i første omgang nye sanktioner mod Serbien.

Imidlertid var Frankrig og Italien imod, og decideret fjendtlige over for UÇK, og det samme gjaldt Rusland. Alle ønskede de en mere afbalanceret strategi og en sikring af, at Kosovo ikke blev løsrevet. Vestmagterne kunne dog enes om visse sanktioner mod Serbien, men bagefter brød der uenighed ud mellem Albright og hendes europæiske kolleger om, i hvor høj grad Milosevic faktisk var kommet deres krav om moderation over for albanerne i møde. Det var afgørende for hende "ikke at skuffe dem, der vendte sig imod Amerika for at finde lederskab." Hun refererer, at hun havde afvist et kompromisforslag fra sin medarbejder Jamie Rubin med ordene: "Jamie, tror du, at vi er i München?" (Albright, 2003, s. 382).

Modstanden i kontaktgruppen overbeviste $\mathrm{Al}$ bright om, at den ikke egnede sig til den resolutte politik, hun fandt nødvendig. Italienerne var for optaget af deres handelsinteresser med Serbien og Frankrig, og Tyskland ville nødig udfordre Rusland, som protesterede mod sanktionerne. Hun mødte også modstand på hjemmebanen fra det nationale sikkerhedsråd og fra forsvarsministeriet. Med britisk støtte forsøgte Albright derfor at bruge NATO og samtidig bygge et politisk kompromis op i regionen baseret på tilbagetrækning af serbiske styrker og skabelsen af et samarbejde mellem Rugova og Milosevic som baggrund for et hjemmestyre i Kosovo. Når heller ikke hun ville støtte de kosovoalbanske ønsker om løsrivelse, var det fordi Makedonien og Grækenland var imod, og fordi det kunne inspirere andre mindretal som tjetjenerne, abkhaserne, kurderne og baskerne. Men hun måtte konstatere, at når Milosevic under pres fra kontaktgruppen trak sine ekstra sikkerhedsstyrker ud af provinsen, benyttede UÇK det til at udvide sine egne positioner. 


\section{UÇK bliver en selvstændig faktor i mediekrigen}

Amerikanerne støttede sommeren 1998 Rugovas forsøg på at blive genvalgt som Kosovos uofficielle præsident, men UÇK nægtede at acceptere det. Albright måtte ved denne som ved senere lejligheder erkende, hvor svært det var at styre kosovoalbanerne, og hvor negativt UÇK og dens militante holdning var vurderet i de fleste EU-lande. Derfor var det ikke populært, at Albright sendte Richard Holbrooke til Kosovo for at forhandle med UÇK - hvilket blev dygtigt udnyttet af denne til at lave videooptagelser af Holbrooke side om side med en uniformeret og bevæbnet UÇK-mand, der pludselig masede sig ned ved hans side på gulvet i et tætpakket hus.

UÇK-folkene fik her et gennembrud i deres forsøg på en effektiv branding af deres hær som legitim og velorganiseret. Således lagde de stor vægt på uniformer og symboler og at vise militær disciplin og anstand. Med deres mediemæssige gennembrud i sommeren 1998 tilførte de Kosovodækningen et nyt element ud over tv-billederne af de elendige forhold for de interne flygtninge under sommerens kampe: Billedet af, at kosovoalbanerne ikke kun var ofre, men også aktører, at de aktivt kæmpede for deres frihed, og at de var en værdig allieret (Fledelius, 1999, s. 78). Samtidig gav UÇK's mediestrategi den et forspring for Befrielsesregeringens politiske rival, dr. Rugova og hans parti. Det skulle nu ikke mere være dem, men UÇK, der satte den politiske dagsorden i Kosovospørgsmålet.

UÇK blev også hjulpet af den negative 'branding' af Milosevic, som var en arv fra krigene i Kroatien og Bosnien. Som Albright selv så malende udtrykker det i sine erindringer: "Milosevic havde allerede startet tre krige i Balkanområdet (imod Slovenien, Kroatien og Bosnien). Han syntes parat til at starte en fjerde" (2003, s. 380). Billedet af Milosevic som diktatoren, der blot kunne bestemme, hvis han ville, i analogi med Hitler og Saddam Hussein, blev en matrix, man støbte forståelsen af serbisk politik i. Og en matrix, der fungerede glimrende i medierne.

UÇK's sommeroffensiv i juli 1998 var imidlertid en katastrofe, også humanitært. Albright mistroede ethvert imødekommende skridt fra Milosevic som et forsøg på at vinde tid og splitte NATO, og hun nærede mistillid til både Italien (hvis premierminister Prodi stod parlamentarisk svagt) og Tyskland (som var på vej til at få en 'grøn' udenrigsminister, Joschka Fischer). Hun gik nu åbent efter at få fjernet Milosevic, og den humanitære situation i Kosovo med titusinder af interne flygtninge og flygtninge til naborepublikkerne hjalp hende til at overbevise Clinton om at føre en sådan politik. $\mathrm{Al}$ bright ønskede "at sende den besked til de serbiske forretningsfolk at han skadede business, til det serbiske militær at han inviterede til opløsningen af deres institutioner, og til den serbiske middelklasse at han ødelagde deres håb for en fredelig og blomstrende fremtid" (Albright, 2003, s. 387f). Da den russiske udenrigsminister Ivanov sagde, at Rusland ville nedlægge veto mod en resolution fra FN's sikkerhedsråd om at godkende en militær intervention i Kosovo under henvisning til, at Milosevic havde lovet at trække sine tropper tilbage, svarede hun ham med de temperamentsfulde ord: "Milosevic er en født løgner” (Albright, 2003, s. 389).

Hermed havde Albright gjort det klart, at USA ville handle også uden et FN-mandat. Og det lykkedes hende at få Frankrig, Italien og Tysklands nye forbundskansler Schröder med på en sådan linie af humanitære grunde. Også Danmark sluttede først i oktober 1998 op bag denne linie, hvorefter NATO truede Jugoslavien med bombeangreb, hvis Milosevic ikke gik med til en internationalt overvåget våbenhvile i Kosovo med henblik på afholdelse af valg og en fremtidig hjemmestyreordning for provinsen. Holbrooke blev sendt til Beograd og kom hjem med en accept fra Milosevic. Truslen havde virket, Jugoslavien slap for NATO-bomber, $\mathrm{og}$ våbenhvilen skulle overvåges af OSCE (Organisationen for Sikkerhed og Samarbejde i Europa, med 54 medlemmer inklusiv USA og Canada).

\section{Kosovokrigen 1999}

Det viste sig imidlertid umuligt at få albanerne i Kosovo til at enes om en fælles kurs. I stedet udtalte de sig om hverandre med foragt og holdt sig ikke tilbage fra trusler om vold mod deres egne. Samtidig nærede Albright mistro til Milosevic. Hun indrømmer, at der var voldsakter på begge sider i december 1998, men lagde i januar 1999 ensidigt ansvaret på Milosevic. De europæiske allierede var knapt så overbeviste. Derfor fik fundet af 45 dræbte albanere i landsbyen Racak d. 15. januar en afgørende betydning, da det af den amerikanske leder af OSCE-missionen på stedet for øjnene af tv-kameraerne blev udlagt som en massakre 
begået af serbisk politi. Albright gik nu efter at tvinge Milosevic til at trække de serbiske styrker ud af Kosovo og acceptere en hjemmestyreordning garanteret og overvåget af NATO-styrker.

Hun havde mange problemer, også i sit bagland, hvor Pentagon stillede sig på bagbenene. Nølende gav forsvarsministeren og forsvarsstaben deres samtykke til en begrænset aktion, der involverede trussel om NATO-flyangreb, men ikke til amerikansk deltagelse i en eventuel fredsbevarende styrke i Kosovo, medmindre det skete med samtykke fra Beograd. Det tilsagn lod hun sig nøje med og vendte sig så mod den 6-magts kontaktgruppe, hun tidligere havde opgivet som håbløs, for at få etableret en fredskonference i eller ved Paris - det sidste for at give franskmændene værtsskabet og æren.

Serbien gik med til fredsforhandlingerne i Rambouillet, ligeså kosovoalbanerne, som både var repræsenteret af moderate politikere og UÇKfolk. Overraskelsen var, at serberne viste sig mere imødekommende end albanerne, som ikke ville acceptere andet end en garanti for fuld løsrivelse. Albright forsøgte at appellere til den unge UÇKleder Hashim Thaçi som en ung demokratisk leder, men albanerne satte sig på bagbenene og ville ikke underskrive rammeaftalen. Det lykkedes hende først at få en underskrift fra den albanske delegation ved at spille nogle af de andre albanske delegater ud mod Thaçi.

Man skal altid være forsigtig med de politiske aktørers erindringer. Men de detaljer, Albright giver af sit politiske pokerspil, passer på billedet af en politiker, der var overbevist om, at en krig imod Milosevic var det rigtige, og som ved hemmeligholdelse og intriger også fik den.

At kalde Kosovokrigen (som officielt aldrig hed en krig, men en "militær intervention") for "Madeleine's War" er ingen tilsnigelse. Albright var en mester i informationsstyring. Hun fik sit politiske og militære bagland manøvreret på plads ved at gå forsigtigt frem og skjule sine sande hensigter. Det samme gjaldt over for de allierede. NATO befandt sig i sit 50. år, årsdagen faldt midt under krigen. Det var en faktor, hun også spillede på.

Der var især tre vigtige elementer i Albrights informationsstyring: 1) At undgå at den indre uenighed og stejle holdning hos albanerne blev kendt. 2) At undgå at den uventet imødekommende holdning fra serbisk side blev kendt. 3) At kaste røgslør over det egentlige indhold i det aftale- kompleks, man til sidst forelagde serberne. Alle tre ting lykkedes i forbløffende grad.

\section{Den effektive brug af negativ branding}

Albright fastholder i sine erindringer sin tendentiøse udlægning af den serbiske politik og sin fortielse af vigtige oplysninger som rækkevidden af de krav, Milosevic blev stillet overfor. Hun nævner således ikke det militære tillæg til Rambouillet-aftalen, hvorefter NATO skulle have adgang ikke blot til Kosovo, men til hele Jugoslavien - et krav som bærer klare mindelser om det østrig-ungarske ultimatum til Serbien i 1914, og som skulle sikre det serbiske nej, man havde brug for for at begrunde angrebet. Det militære tillæg blev først lækket til internettet et godt stykke inde i krigen - ad franske kanaler. Og Albrights bagatellisering af det serbiske modforslag i Rambouillet få dage før krigen svarer i dag ganske til den ignorering af det som irrelevant og utilstrækkeligt, som fremgik af de vestlige medier dengang. Hendes overordnede formål er udtrykt sammesteds i hendes replik til præsident Clinton ved et møde d. 19. marts: "Hør, lad os ikke glemme årsagen til at bruge magt til at bremse Milosecivs bølle-opførsel nu og her. Der er ingen garanti for, at det vil lykkes, men alternativerne er værre. Hvis vi ikke reagerer nu, vil vi være nødt til at reagerer senere, måske i Makedonien, måske i Bosnien. Milosevic valgte denne her kamp. Vi kan ikke lade ham vinde" (Albright, 2003, s. 406).

Dette var præcis en reference til vestens München-traume. Albrights parallel mellem Hitler og Milosevic er åbenbar og fungerede fint i den aktuelle kontekst. Hun fik skabt et klima af "nu eller aldrig". At hendes analyse af serbisk indenrigspolitik var overfladisk og hendes psykologiske vurdering af Milosevic forkert, forhindrede ikke hendes synspunkter $\mathrm{i}$ at blive accepteret $\mathrm{i}$ de fleste medier og hos NATO-partnerne, hvoraf muligvis kun briterne kendte den afgørende detalje i det militære tillæg til Rambouillet-kravene. Således blev hendes version glat accepteret af CNN (Herman \& Peterson, 2000, s. 115-7). Hun var lige så målrettet i sin negative branding af Milosevic som senere den yngre Bush-administration af Saddam Hussein. Og vi finder den samme målrettede styring og udlægning af informationerne.

Albrights negative branding af Milosevic og serberne blev fulgt fint op af briterne med pre- 
mierminister Tony Blair, udenrigsminister Robin Cooke og forsvarsminister George Robertson i spidsen. Deres "nazificering" af serberne blev fulgt op af tyskerne og var med til at bryde deres traditionelle modstand mod igen at intervenere militært i udlandet (Hume, 2000, s. 70-8; Hammond \& Herman, 2000, s. 123-31).

Men også kosovoalbanerne kunne kunsten. De fik skabt et billede under krigen af massakrer på hundredtusinder af civile, som vandt tiltro hos mange. En journalist ved Danmarks Radio, Thomas Ubbesen, fortalte ved en høring efter Kosovokonflikten, hvorledes han havde søgt jugoslavisk visum for at komme til Beograd, så han kunne være der under bombningerne. Men han havde fået afslag, fordi regeringen i Beograd rutinemæssigt gav afslag til journalister fra NATO-landene på grund af konflikten. Det havde han ærgret sig over, derfor var han taget til et af nabolandene og havde der interviewet de albanske flygtninge, som strømmede ud fra Kosovo. Og tænk, sagde han, hvis jeg nu havde fået det visum, så havde jeg lavet en helt anden reportage end dén, jeg nu sendte med de albanske flygtninge som kilde. Så havde mine historier nok været præget af medfølelse med serberne, ikke med albanerne. Derfor var han i dag glad for, at han ikke havde fået sit visum.

Historien illustrerer tre ting: Den ene er den helt håbløse mediestrategi, den serbiske side i konflikten valgte. I krænkethed over NATO-landenes holdning forsømte man totalt at give journalister fra disse lande mulighed for at tage konsekvenserne af bombningerne i øjesyn, og mistede dermed en mulighed for at påvirke befolkningerne i fjendeland. Ảbenbart regnede man med, at de allerede var så forudindtaget, at det hele kunne være det samme. Den serbiske side gjorde det således ikke lettere at sikre en afvejet nyhedsrapportering fra konflikten. Her havde Saddam Hussein været klogere under Golfkrigen i 1991, da han lod amerikaneren Peter Arnett rapportere til CNN fra Bagdad.

Den anden ting, historien illustrerer, er, at journalisten åbenbart mente, at det grundlæggende ville have ændret hans holdning til konflikten, hvis han havde befundet sig hos den anden part. Det var et meget oprigtigt udsagn, selv om det jo aldrig kom på prøve, fordi Ubbesen aldrig fik mulighed for at opleve konflikten fra den serbiske side. Hans reportager fra samtaler med flygtende albanere viste imidlertid en klar stillingtagen mod serberne og en tiltro til, at flygtningene talte sandt - noget som siden har vist sig ikke altid at være tilfældet. For også mange af de albanske flygtninge kendte deres rolle i informationskrigen. Nu sørgede serberne selv for, at det kun var deres stemme, der blev hørt i Danmark. En anden dansk journalist oplevede således efter konflikten, at hun gerne ville følge op på nogle af de flygtningeskæbner, hun havde mødt, og skrive om, hvordan det var for dem at vende tilbage. I et bestemt tilfælde talte hun med én, som havde berettet, hvordan hun havde set sin familie blive dræbt - nu glædede hun sig til at komme hjem til Prishtina og gense dem! Historien illustrerer, at journalister ofte stiller sig mindre kritisk til informationer fra den side, de kommer til at opleve som 'deres egen', og dermed kan blive til et talerør for den. Ligesom objektivitetsidealet kan komme til at blive overskygget af en ubevist iagttagelse af 'politisk korrekthed'.

Der er ingen tvivl om, at der fra serbisk side blev sat en masseuddrivelse af etniske albanere i gang, så snart forhandlingerne i Rambouillet var brudt endeligt sammen i marts 1999. Men der var ikke tale om de vældige massedrab, som flygtningeberetningerne lagde op til, og samstemmigheden mellem flygtningenes beretninger burde have tændt advarselslys hos de journalister, som tog deres beretninger for gode varer.

\section{Konsekvenserne af parternes informationsstrategi}

Den officielle NATO-rapportering bar imidlertid hovedansvaret for den alvorligste forskydning af helhedsbilledet. Selv i dag fremstilles den "humanitære intervention" i Kosovo ofte som en indgriben mod et igangværende folkemord. Men massefordrivelserne begyndte først for alvor omkring starten af bombardementerne. Den serbiske nyhedsformidling søgte at forklare strømmen af albanere ud af Kosovo med, at de flygtede for NATOs bomber. Da ingen tog den historie for gode varer, og da det var klart, at de flygtende albanere repræsenterede et voksende imageproblem for serberne, forsøgte regeringen i Beograd at overtale albanerne i Kosovo til at vende om. Det fik den dog ikke noget ud af. Skaden var sket. Milosevic og kredsen omkring ham blev stemplet som krigsforbrydere og gjort internationalt fredløse.

Det var også NATO-kilder, der lå bag et tilbageblik over udviklingen frem til krigsudbruddet $\mathrm{i}$ marts, som blev bragt i Berlingske Tidende den 13. 
april 1999, første sektion, "Kosovo skulle renses for albanere", skrevet af journalist Lene Frøslev. Indledningsvis skrev hun - med forsigtighed og forbehold - om "Operation Hestesko", en angiveligt af Milosevic udarbejdet langsigtet plan for at fjerne et flertal af Kosovos albanske befolkning fra provinsen (planens eksistens er heller ikke siden blevet bevist). Journalisten refererer også korrekt, at general Momcilo Perisic, som hørte til de moderate hærfolk, var blevet afskediget i november 1998, og at politikeren Vuk Draskovoc, moderat i forhold til andre af regeringens medlemmer, også havde forladt den. Men derefter refererer journalisten, hvorledes serberne siden december 1998 konsekvent har optrappet konflikten trods våbenhvileaftalen fra oktober 1998. De episoder, hun nævner, er korrekte nok, omend noget tendentiøst gengivet. Men alle de voldshandlinger er udeladt, som var begået af UÇK. I realiteten havde så godt som enhver serbisk voldshandling siden december 1998 været et svar på en forudgående albansk, bortset fra det serbiske angreb på en smuglerkolonne, som forsøgte at bringe våben over bjergene fra det nordiske Albanien. Det hele var en krig på lavt blus fra begge sider, der blev omhyggeligt overvåget af den internationale observatørstyrke, der var indsat fra oktober 1998 - det var ikke en kæde af uprovokerede serbiske overgreb, men menneskerettighedskrænkelser fra begge sider. Dette fremgik af OSCE's informationer, som også havde fundet vej til danske aviser i december og januar. De albanske brud på våbenstilstanden, som en kosovoalbaners nedskydning af civile serbere i en café lige før jul og kidnapningen af otte serbiske soldater lige efter nytår, var imidlertid udeladt. Det var den 'faktuelle' måde, NATO-kilderne opsummerede begivenhedsforløbet på, og som den danske journalist overtog. Det samme gjaldt påstanden om, at forhandlingerne i Paris i marts "reelt var blevet saboteret af den serbiske delegation". Artiklen var absolut et stykke sober journalistik med forbehold over for den dubiøse "Operation Hestesko". Men den 'almenviden', den byggede på, var tilrettelagt af NATO for at give et billede af forløbet, som kunne legitimere iværksættelsen af luftbombardementerne - den fungerede ikke ved direkte usandheder, men ved systematisk selektion. Det overvejende flertal af danske journalister skrev ganske som Lene Frøslev om disse "enkle fakta", og i Fyllandspostens leder den følgende dag var enhver tvivl om "Operation Hesteskos" ægthed væk.
Efter krigen var startet, og Danmark var blevet involveret ved at stille enkelte fly til rådighed for flybombardementerne, var der i det hele taget en tendens i de danske medier til at acceptere krigen som nødvendig og retfærdig - den konservative Hans Engell gik så vidt som til offentligt at skælde Venstres formand Anders Fogh Rasmussen ud, fordi han havde kritiseret statsminister Poul Nyrup Rasmussen for ikke at have en tilstrækkelig klar og utvetydig holdning til krigen - man kritiserede da ikke nationens leder, når man var i krig! Først efter krigens afslutning fik kritikken igen vind i sejlene.

Fra serbisk side var mediestrategien katastrofal. Ofte var de serbiske informationer korrekte nok, men de blev serveret i et så værdiladet sprog, at alt blev opfattet som propaganda i modstanderlandene. Almindelige serberes demonstrationer på broerne i Beograd mod NATO havde i øvrigt nær udløst et bombardement - en amerikansk general syntes ikke, at de skulle have lov at håne NATO. Serberne var klar over, at der var planer om at bombe tv-højhuset i Beograd, og studieværten spøgte selv med det i den sidste udsendelse, før bombningen faktisk fandt sted. Ved natangrebet d. 21. april omkom fire personer, der var kaldt ind på vagt. Meget tyder på, at angrebet var varslet, og at de kun var blevet kaldt på arbejde, fordi regimet havde brug for at hænge angriberne ud for et barbarisk overgreb mod ytringsfriheden.

Den officielle begrundelse for at bombe tvtårnet var, at Milosevics propaganda forlængede krigen. En anden og mere nærliggende grund kan have været, at serbisk tv faktisk havde formidlet flere pinlige fejltagelser fra NATO-side, som onsdag d. 14. april da en kolonne med 75 albanske flygtninge i Kosovo blev ramt, eller da et fly kort forinden ødelagde en bro, netop som et tog kørte ud på den. En anden grund til angrebet kan have været at vise beslutsomhed omkring tidspunktet for NATOs 50-års jubilæumsmøde i Washington D.C. Faktisk forsøgte NATO at holde civile ofre for sin "humanitære intervention" på så lavt et niveau som muligt - hvilket også lykkedes. Tabene for militær og politi var primært materielle.

Det lykkedes dog ikke NATO at få sat serbernes elektroniske medier helt ud af spillet, og et sted kunne NATO ikke gribe ind: over for den intensive serbiske brug af internettet. Man har kaldt Kosovokrigen for den første internetkrig, amerikanerne forsøgte at hacke jugoslaviske regeringscomputere, mens serbiske hackere forsøgte at angribe 
NATO-netværk. Dette var dog mest af symbolsk betydning. Væsentlig mere betydningsfuld var informationsvirksomhed på engelsk på nettet, her fik serbiske informanter uforstyrret global rækkevidde. 'Cyber-munken' Sava i Decani-klostret kom til at spille en særlig rolle som en uafhængig informationskanal, der var kritisk over for både NATO og Milosevic (Gocic, 2000, s. 91).

\section{Laren af Kosovo}

Til en vis grad var Kosovokrigen - eller den "humanitære intervention" som den formelt blev kaldt frem for krig - mediemæssigt og militært en succes og en bekræftelse af NATO-samarbejdets styrke og formåen, og tilsyneladende også en bekræftelse af den såkaldte Glinton-doktrin (at det er muligt at sejre alene gennem brug af luftangreb). At diplomatiet spillede en afgørende rolle for udfaldet, herunder at der i virkeligheden blev givet væsentlige indrømmelser til den serbiske side i forhold til Rambouillet-kravene, er noget, man siden er gået lettere henover (Gowan, 2000, s. 45-47). Der er stadig danskere, der accepterer det officielle billede af Kosovokonflikten og ser en krig mod Saddam Hussein som en naturlig ting på den baggrund. Eller omvendt kritiserer Irakkrigen for at stå i modsætning til den 'retfærdige' Kosovokrig. Den sidste holdning er især blevet udbredt, efter det har vist sig, at den højt profilerede amerikanske mediekampagne for eksistensen af masseødelæggelsesvåben i Irak viste sig utroværdig, og efter at den amerikanske position er blevet yderligere undergravet af billederne af tortur af fanger i det besatte Irak.

Men allerede amerikanernes styring af informationerne for og under Kosovokrigen viser, at man heller ikke dengang veg tilbage fra at levere sine allierede halve og kvarte sandheder. Der var derfor i militære NATO-kredse i Europa (måske med undtagelse af Storbritannien) en klar fornemmelse af, at man sagtens kunne blive misinformeret af sine venner og derfor måtte opretholde sig eget efterretningsvæsen. Når Kosovokrigen alligevel hos en del europæiske politikere blevet stående som 'den retfærdige krig' i modsætning til Irakkrigen, er det fordi, man under Kosovokrigen var dygtigere til at skjule de problematiske aspekter af krigens forhistorie og forløb.

Man kan ikke påstå, at informationsstyringen var perfekt under Kosovokrigen. NATOs talsmænd kom ofte i nærmest gidselagtige situationer, fordi de ikke var ordentligt informeret af deres bagland og derfor ikke kunne svare på opdukkende problemer som toget på broen, den albanske flygtningekolonne eller missilet mod den kinesiske ambassade i Beograd. Faktisk var mediestaben i Bruxelles underbemandet ved krigens udbrud, da mange af Jamie Sheas medarbejdere befandt sig i Washington D.C. på grund af NATOs forestående jubilæum. Det blev der så efterhånden rettet op på. Men Shea har siden gentagne gange talt om, hvor meget NATOs talsmænd dengang var nødt til at improvisere. Og så var de som deres bagland præget af en ensidig opfattelse af magtforholdene i Serbien og ledelsens intentioner. Det var således ikke engang i juni 1999 gået op for den britiske forsvarsminister George Robertson, at den virkelige fjende for serberne ikke var NATO, men UÇK, $\mathrm{og}$ at det derfor gjaldt for dem om ikke at rømme deres stillinger hurtigere, end at NATO kunne nå at besætte dem. At NATO for serberne efter krigen mere opfattedes som en allieret mod UÇK end som en modstander var vanskeligt at begribe efter den dæmonisering, der havde fundet sted af dem. Det var først Hans Hækkerup, der som international 'statholder' i Kosovo efter Milosevics fald i efteråret 2000 fik rettet op på det, og givet serbiske styrker mulighed for at rykke ind i grænseområderne til Kosovo, hvor der havde udviklet sig en pendant til UÇK.

I Serbien blev regeringen i endnu højere grad fange af sin egen informationspolitik efter at have udlagt fredsslutningen i Beograd i juni 1999 som en sejr. Det er rigtigt, at fredsbetingelserne var væsentlig mildere end det ultimatum, som blev stillet i marts. Dengang havde man under hånden skruet kravene til serberne op ved at forlange, at de skulle åbne hele Jugoslavien, ikke blot Kosovo, for NATOs styrker. Det krav var blevet droppet (spørgsmålet er naturligvis, om det nogensinde har været alvorligt ment, måske lige med undtagelse af Madeleine Albright selv). Og det er også rigtigt, at Beogradfreden fastslog FN-resolution $1244 \mathrm{og}$ dermed Kosovoprovinsens fortsatte tilhørsforhold til Jugoslavien. Men på den baggrund var det svært at forklare befolkningen i det øvrige Serbien, hvorfor der strømmede serbiske flygtninge mod nord fra Kosovo. Det blev så pinligt, at man forbød dem at tage til Beograd. Til gengæld har de hobet sig op i det centrale Serbien. Derfor kom Milosevic til at stå som utroværdig. også hos sin egen befolkning, hvilket førte til hans fald i efteråret 2000. 


\section{Fra Kosovo til Irak}

Heldigvis ser det ud til, at den almindelige skepsis er øget over for ikke blot fjendens, men også vore allieredes informationer. Det har vist sig, at den opdigtede nyhed med kuvøsebabyerne under den irakiske besættelse af Kuwait i 1990 ikke var et enkeltstående eksempel. I Kosovokrigen drejede det sig især om konsekvent undertrykkelse af vigtige fakta. I opstarten til Irakkrigen i 2003 er det den tendentiøse tolkning af luftfotos (et gammelt redskab fra Vietnamkrigen) og anden dokumentation og en konsekvent nedtoning og bortfortolkning af modpartens imødekommende skridt, som er midlerne til legitimering af angreb. Et trusselsbillede er blevet bygget op, som viste sig uden hold i virkeligheden. Endnu værre er det gået med informationsstyringen efter krigen, hvor det ikke har været muligt for det amerikanske militær at forhindre, at

\section{Litteratur}

Ackerman, S. \& Naureckas, J. (2000). Following Washinton's Script: The United States Media and Kosovo. In Hammond \& Herman (Eds.), Degraded capability. The media and the Kosovo crisis. London: Pluto Press.

Albright, M. (2003). Madame Secretary: A memoir. Macmillan Publishers.

Fledelius, K. (1999). Jugoslaviens sygdom og død. København: Gyldendal.

Fledelius, K. (2003). Gescheiterter Atheismus? Staat und Glaubensgemeinschaften in Albanien, Bulgarien und Jugoslawien (1945-1992). In Maser \& Schjørring, Wie die Träumenden? Protestantischen Kirchen in der Phase des Zusammenbruchs der kommunistischen Herrschaft im östlichen Europa. Erlangen: Martin-Luther-Verlag.

Gocic, G. (2000). NATO versus the Serbian media. In Hammond \& Herman (Eds.).

Gowan, P. (2000). The war and its aftermath. In Hammond \& Herman (Eds.).

Hammond \& Herman (Eds.). (2000). Degraded Capability. The Media and the Kosovo Crisis. London: Pluto Press.

Kolar-Panov, D. (1997). Video, war and the diasporic imagination. London: Routledge. amatøroptagelserne af amerikansk personels tortur af irakiske fanger nåede ud til offentligheden.

Noget sådant undgik man i Kosovo. Her lykkedes det at opretholde billedet af den humanitære trussel, man brugte som begrundelse for krigen, og serberne hjalp ved deres egen politik efter krigens udbrud med til at støtte troværdigheden af NATOs propaganda. Det er først efter de etniske uroligheder i marts 2004, at der for alvor begynder at brede sig en forestilling om også Kosovoaktionens problematiske karakter, idet radikale kosovoalbanske nationalisters overgreb mod personer og kirker af serbisk oprindelse har sat fokus på, at de erklærede mål for Kosovokrigen langt fra er realiseret fem år efter NATO-angrebet på Serbien. Der har været udgivet flere kritiske analyser af informationskrigen om Kosovo. Men det er først $\mathrm{nu}$, at tiden indhenter en konflikt, mange gerne ser som en 'retfærdig' Clinton-krig i modsætning til den seneste 'uretfærdige' Bush-krig.

Mertus, J.A. (1999). Kosovo - how myths and truths started a war. Berkeley: University of California Press.

Milinkovic, B. (1993). War Propaganda - the Yugoslav Case. In Malesic (Ed.), The role of mass media in the Serbian-Croatian conflict. Stockholm: Styrelsen for psykologiskt försvar, Rapport nr 164.

Mønnesland, S. (1992). Før Fugoslavia og etter. Oslo: Sypressforlag.

Owen, D. (1995). Balkan odyssey. London: Indigo.

Silber, L. \& Little, A. (1995). The death of Kugoslavia. London: Penguin.

Sommelius, S. (1993). Mediernas krig i forna Jugoslavien. Stockholm: Styrelsen for psykologiskt försvar, Meddelande nr 135.

Thompson, M. (1999). Forging war. The media in Serbia, Croatia, Bosnia and Hercegovina. Luton: University of Luton Press/Article 19.

Karsten Fledelius er lektor ved Københavns Universitet, Institut for Medier, Erkendelse og Formidling, Afdeling for Film- \& Medievidenskab 